land Protectorate, to which he has paid many visits over a period of twenty years, but he has also twice visited East Africa, to advise on the organisation of sociological research there by the local governments and by the Colonial Social Science Research Council. His publications include a general work on the Bushmen and Hottentots and several books on the law, land tenure and social institutions of the Tswana people of the Protectorate. He has also published an important work on "Migrant Labour and Tribal Life in South Africa". Prof. Schapera is one of the most eminent authorities on the social anthropology of the South African Bantu and is interested not only in their traditional way of life but also in the problems presented by their adaptation to Western culture.

\section{College of Aeronautics, Bletchley: A. D. Baxter}

Mr. A. D. BAxper has been appointed to the chair of aircraft propulsion at the College of Aeronautics, as from September 1. Mr. Baxter is at present superintendent of the Rocket Propulsion Department at Westcott of the Royal Aircraft Establishment. $\mathrm{He}$ has served with the Establishment since 1935 and has had a wide experience of internal combustion engines for aircraft. He was among the first to work on gas turbine research and development, and was associated with much of the pioneer work, particularly on the problems of combustion. Towards the end of the War he became responsible for assessment and investigation of all forms of high-speed propulsion units, including the German $\mathrm{V}$ weapons. Mr. Baxter has, for some years, been a member of severel power plants sub-committees of the Aeronautical Research Council.

\section{Woods Hole Oceanographic Institution: Dr. Edward H. Smith}

Dr. Edward H. Smith has been appointed director of the Woods Hole Oceanographic Institution for a period of six years, as from July 1. Columbus O'D. Iselin, director since 1940, will resign his post on that date to become senior oceanographer at the Institution. Dr. Smith, who is at present rear admiral in the U.S. Coast Guard in command of the Coast Guard's Eastern Area and Third District, is well known for his work with the International Ice Patrol. During the War, while in command of a task force, he organised a weather and beacon service across the North Atlantic, which service has now become a permanent international aid to navigation.

\section{T. B. O.borne Medal of the American Association of Cereal Chemists}

THE Thomas Burr Osborne Medal of the American Association of Cereal Chemists has been awarded to Dr. W. F. Geddes, chief of the Agricultural Biochemistry Division, University of Minnesota, for his distinguished contributions to cereal chemistry. Dr. Geddes, who is a Canadian by birth, has been prominent in both teaching and research in the field of cereal chemistry and technology for more than twenty years. He is a past president of the Association, and is the editor of Cereal Chemistry, the official publication of the Association. The Medal has been awarded only seven times previously since it was founded in 1926. The first award was made in 1928 to T. B. Osborne, who was for a long time connected with the Connecticut Agricultural Experiment Station.

\section{Shape of Bubbles and Undifferentiated Cells}

Prof. F. T. Lewis, of Harvard Medical School, has recently published an interesting comparison of the shapes of soap bubbles and of undifferentiated cells (Proc. Amer. Acad Arts and Sci., 77, No. 5, 149 ; 1949). He suggests that the shapes of such cells in bodies of many cells is dependent on the following five major variables. (1) Geometrical necessity : for example, if cells are of a uniform size they will tend towards 14-hedra, though special features may reduce the facet-number below this figure. The peripheral layer of a mass of 14-hedra will consist of 11-hedra, each of the 11-hedra making one surface of contact with the surrounding medium insterad of four with surrounding polyhedra. (2) Surface tension and other forces tending to produce minimal surface area : with bubbles, surface tension can produce examples of unstackable combinations of twelve, fourteen, fifteen and sixteen facets which, if isolated and regular, have the least surface for volume. None of these shapes has yet been found among cells. (3) Cell division : this must involve forces opposed to surface tension, since division increases the total cell surface area. (4) Turgor: this again is opposed to surface tension. (5) Organisation: under this general heading Prof. Lewis includes all the processes whereby growth and division are "controlled to produce filaments, fibres, membranes or compact masses as may be proper for the organism".

\section{Mixed-Bed De-ionization for Treatment of Water}

Erant years ago, the Permutit Co., Ltd., of Gunnersbury Avenue, London, W.4, introduced a new technique in water treatment. This involved the use of mixed cation-and anion-exchange materials for producing high-quality demineralized water in a single step. The process has been developed, and, by the use of recently developed ion-exchange materials, it provides in a single treatment water with an electrical resistance of more than ten million ohms per centimetre cube and free from carbon dioxide and silica. The ion-exchange materials employed are 'Zeo-Karb 315', a very stable resin containing sulphonic acid groups, and the newly developed highly basic anion exchanger 'De-Acidite $F$ '. When a mixed bed is used for treatment of water which has been previously distilled or demineralized by a normal technique, the effluent is of a quality previously unobtainable without multiple distillation and is suitable for use as conductivity water and in traceelement work. A further advantage is that deionization takes place in neutral solution, so that acid-sensitive solutions, for example, blood plasma or sugars liable to inversion and mutarotation, can be treated. Known as 'Bio-Deminrolit', the mixed ion-exchange material is finding an increasing number of uses.

\section{Arthropod Embryology}

The Onychophora occupy a unique position in the animal kingdom and are generally regarded as lying near the base of the Arthropoda. A study of their embryonic development, therefore, is of interest not only for students of that class but also because of the light it may throw upon the embryology of the higher and more specialized classes. The material is not easy to obtain, and much of the early work suffers from inadequate technique. The first interest of a recent work by Dr. S. M. Manton ("Studies on the Onychophora, 7 : the Early Embryonic Stages of 